\title{
Facies and geochemistry of non-marine gypsum, EMISAL, Egypt
}

\author{
M. W. ALI-BIK ${ }^{\left|1,{ }^{*}\right|}$ H. I. M. METWALLY ${ }^{|1|}$ A.M.A. WALI ${ }^{|2|}$ M.G. KAMEL $^{|3|}$ \\ ${ }^{11}$ Geological Sciences Department, National Research Centre, Dokki, Cairo, Egypt \\ ${ }^{|2|}$ Geology Department, Faculty of Science, Cairo University, Egypt \\ ${ }^{|3|}$ Academy of Scientific Research and Technology, Cairo, Egypt
}

${ }^{*}$ Corresponding author: E-mail: mwalibik2007@yahoo.com

\section{A B S T R A C T}

Diverse gypsum facies in terms of crystal size and morphology are deposited in a shallow, non-marine, sulfateenriched, semi-closed, perennial evaporite basin. These gypsum facies were deposited in intimate association with cyanobacterial mats. Facies analyses and geochemistry revealed two distinct primary facies, based on gypsum fabric; massive selenite, and laminated gypsum varieties. The massive selenite facies is composed of clusters of single and twinned crystals along (100), with upward pointing re-entrant angle. The laminated gypsum varies from rhythmically laminated grass-like selenite to gypsum microbialite (stromatolite). The change from massive selenite to laminated gypsum facies implies fluctuation in lateral and vertical salinity profiles, seasonal brine concentrations and wind action. Post-depositional changes in the form of dissolution, slight to moderate crystal deformation and recrystallization to anhydrite are evaluated. We develop a qualitative model for the depositional basin and facies distribution in order to simulate ancient analogues.

KEYWORDS $\quad$ Gypsum. Lithofacies. Non-marine. Geochemistry.

\section{INTRODUCTION}

Marine and non-marine evaporites have formed in various modern and ancient depositional settings including marginal (mixed shallow-subaqueous and subaerial), shallow- and deep-subaqueous environments (e.g. Schreiber and El Tabakh, 2000). Evaporite basins vary from small lake/lagoon to large intracratonic/rift scale (Tucker, 2001). Data of evaporite deposits from artificial salinas is crucial in understanding shallow-water evaporite depositional environments. The current interpretations of ancient sulfate lithofacies are mainly based on data from modern analogues, where original sedimentary and early diagenetic features are traceable (e.g. Warren and Kendall, 1985; Cody and Cody,
1988; Cornée et al., 1992; Schreiber and El Tabakh, 2000; Kasprzyk, 2003) and on experimental data from chemically precipitated phases (Cody and Cody, 1989). In general, the observed gypsum facies in recent shallow subaqueous environments represent the most common rock assemblages of ancient deposits (e.g. Ortí Cabo et al., 1984a; Schreiber and El Tabakh, 2000); hence, they can serve as reasonable representations of ancient analogues. Detailed studies of modern evaporites that evolved under known depositional and physico-chemical conditions are important for deciphering the origin of ancient analogues. A number of depositional models for selenite facies have been postulated (e.g. Hardie and Eugster, 1971; Warren, 1982; Ortí Cabo et al., 1984a; 1984b; Babel, 2004). 
Facies analysis, in general, is a fundamental tool in inferring the paleo-topographic and climatic conditions that prevailed during the formation of ancient primary evaporites. Hence, detailed macroscopic and microscopic investigations can elucidate the depositional history and environmental characteristics of such deposits (e.g., Hardie and Eugster, 1971; Shearman and Ortí Cabo, 1976; Ortí Cabo and Shearman, 1977; Schreiber, 1978; Ortí Cabo et al., 1984a; Ciarapica et al., 1985; Kasprzyk, 1999 in Kasprzyk, 2003; Peryt, 2001; Babel, 2005; 2007; Becker, 2005; Babel et al., 2011).

The concentration pond no.3 at EMISAL (longitude $30^{\circ} 14^{\prime} \mathrm{E}$, latitude $29^{\circ} 26^{\prime} \mathrm{N}$ ) in the continental Lake Quaroun (Fig. 1) provides a good example of different primary gypsum facies deposited under controlled physico-chemical conditions. These gypsum facies were accumulated over the past few decades by the evaporation of non-marine, sulfate-enriched brines, in variable environments. Hence, the detailed study of these deposits gives a good opportunity to evaluate the formation conditions of ancient analogues.

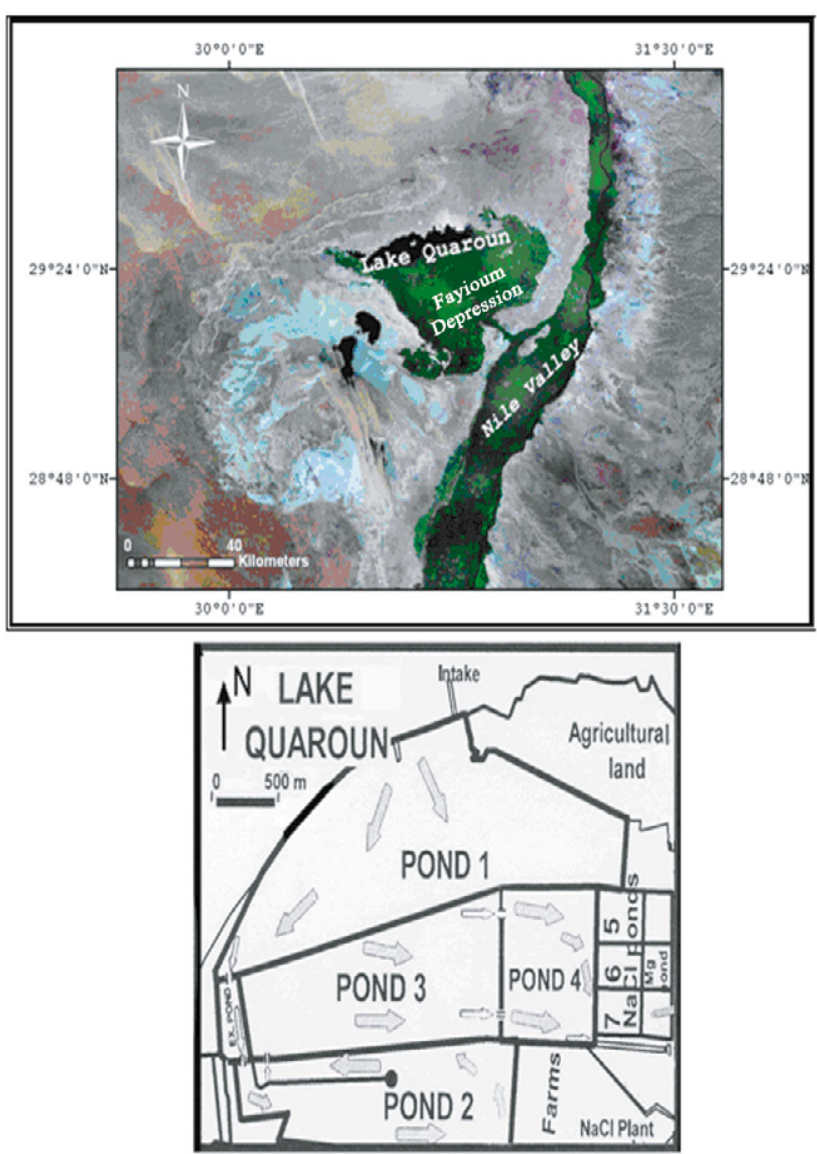

FIGURE 1 Satellite image of Fayioum depression in Lake Quaroun (Mosaic_Landsat/N-36/N-36-20.ETM-EarthSat-MrSID) and a sketch of the concentration ponds of EMISAL.

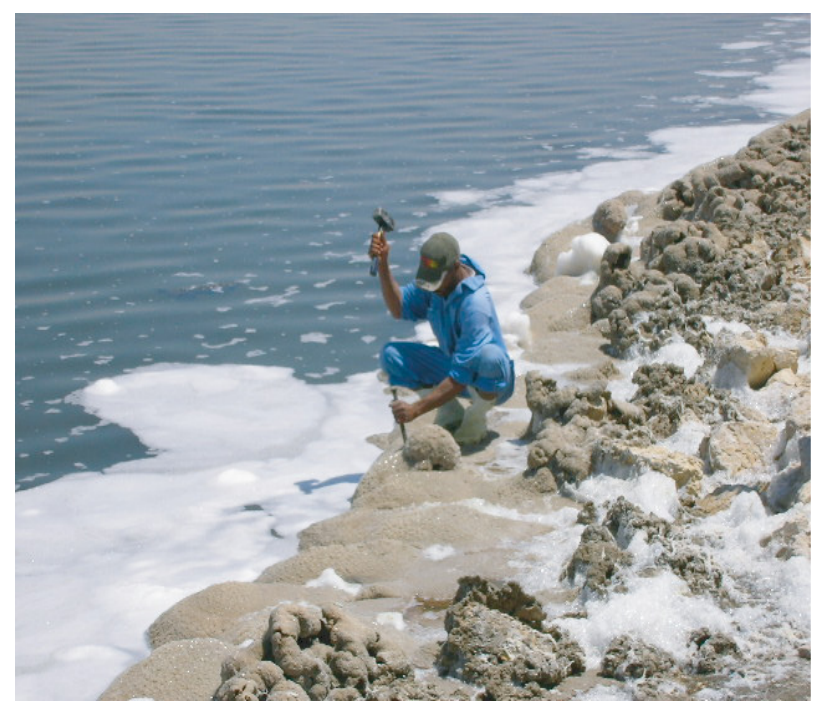

FIGURE 2 $\quad$ Gypsum exposure at the southern bank of pond no. 3.

In the present work, facies analysis, post-depositional changes (diagenesis), and geochemistry of the different gypsum facies, are given. In addition, a qualitative model of the basin and distribution of the gypsum facies is postulated.

\section{SETTING}

The rocky, low altitude platform of the Egyptian Western Desert is characterized by conspicuous natural depressions of various sizes (e.g. Said, 1962; Embabi, 2004). The latter author distinguished nine mega depressions $\left(>1000 \mathrm{~km}^{2}\right)$, among them the Fayioum depression $\left(\sim 2580 \mathrm{~km}^{2}\right)$ which reflects both desert and Nile Valley signatures is outstanding (Fig. 1). In spite of the debate about the origin of these depressions, the role of erosion and wind action in their morphology is widely accepted (e.g. Said, 1960; Embabi, 2004). Owing to differential erosion of interbedded resistant and soft rocks, the borders of these depressions are mainly outlined by mesas and cuestas.

According to Beadnell (1905), the lithostratigraphic section of the Fayioum depression covers a time-span from middle Eocene to Pleistocene. It comprises marine, fluviomarine and lacustrine deposits. Generally, the depression is characterized by the presence of recycled ancient lakebeaches and lacustrine sediments, implying sporadic connections with the Nile since middle Pleistocene (Embabi, 2004 and references therein).

The Lake Quaroun is the lowest topographic part of the Fayioum depression ( $\sim 45 \mathrm{~m}$ below sea level). It represents the remains of the pre-historic Lake Moeris (Said, 1962), which covered a large part of the Fayioum depression. The Lake Quaroun collects the excess of irrigation and the 
agricultural waste-water from the surrounding cultivated lands (Fig. 1) and receives about 60.000 tons of dissolved salts per year from leached surface crusts and fertilizers (Embabi, 2004). $\mathrm{Na}^{+}, \mathrm{Ca}^{2+}, \mathrm{Mg}^{2+}, \mathrm{Cl}^{-}$and $\mathrm{SO}_{4}{ }^{2-}$ are the major cations and anions in the lake water. Local climatic conditions of the area have been discussed in detail by many authors (e.g. Samy, 2000; Al-Kordy, 2003; Ali and El Sheikh, 2004). Generally, the region is characterized by hot daytime temperatures $\left(35^{\circ} \mathrm{C}-45^{\circ} \mathrm{C}\right.$ during summer months) and dry conditions (relative humidity ranges from 64 to $33 \%$ ) with scarce rainfall ( $\leq 10 \mathrm{~mm}$, annually). The velocity of the dominant wind in the area (from northnorthwest to south-southeast), ranges from 2.74 to $5.16 \mathrm{~m} / \mathrm{s}$. Owing to the arid and dry climate of the area, considerable amounts of water are lost annually by evaporation. Thus, the salinity of the lake has been increasing dramatically, reaching about $35 \mathrm{~g} / 1$ at present. In comparison with seawater, Lake Quaroun water is richer in $\mathrm{SO}_{4}{ }^{2-}$ and $\mathrm{HCO}_{3}{ }^{-}$ by factors of 3.56 and 2, respectively, and depleted in $\mathrm{K}^{+}$ and $\mathrm{Cl}^{-}$by factors of 0.57 and 0.67 , respectively (Ali and El Sheikh, 2004).

Based on environmental and economic reasons (White Young and Partners, 1976; DSS-Engineers, 1979), the EMISAL project (Fig. 1) was developed in the Lake Quaroun to extract $\mathrm{Na}_{2} \mathrm{SO}_{4}$, edible $\mathrm{NaCl}$ and $\mathrm{Mg}$-salts. The salt-extraction process is based on brine-concentration technology via controlled evaporation-precipitation cycles
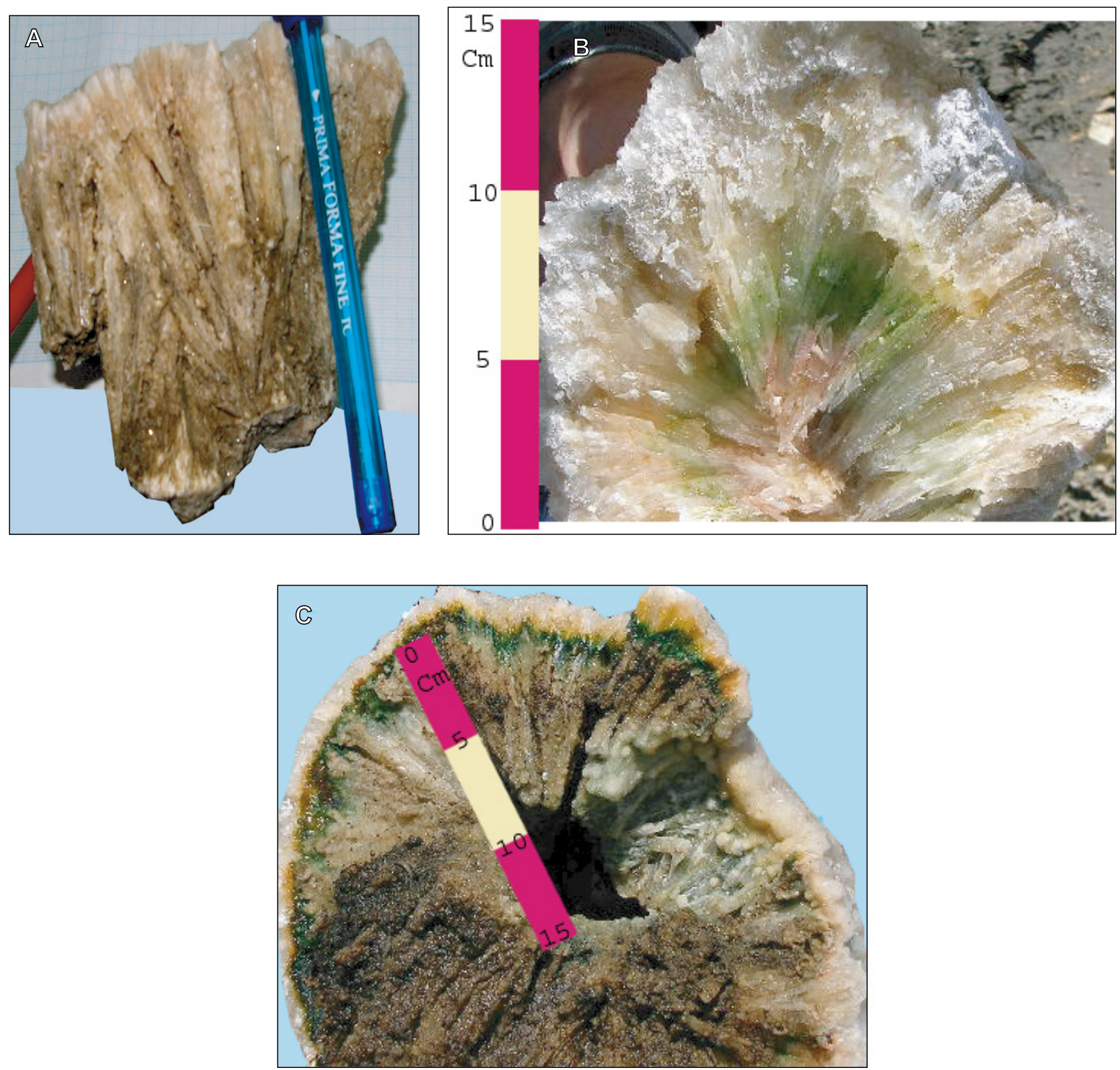

FIGURE 3 A) Single and twinned selenite crystals forming the massive selenite facies. B) A palmate pattern (fan-like) of upward-grown selenite crystals in the massive selenite facies. C) A cross section ( $\perp$ to the twin plane) exhibiting a radial pattern. 
using the solar energy, throughout four successive ponds of about $5.3 \mathrm{~km}^{2}$. Based on local meteorological information, four successive concentration ponds were designed with adjusted depths of $1.7 \mathrm{~m}, 1.80 \mathrm{~m}, 2.3 \mathrm{~m}$ and $2.8 \mathrm{~m}$ deep, to allow natural flow of the brine from one pond to another, via controlled gates (Fig. 1).

Concentration ponds nos. 1,2 and 3 cover areas of about $4.82 \mathrm{~km}^{2}$, representing successive evaporation basins with different degrees of salinity. Clays and other suspended materials, as well as part of the carbonate ions, are eliminated in pond no.1, by settling and crystallization, respectively. The complete precipitation of carbonates (mainly in the form of aragonite) is achieved in pond no.2, while, the precipitation of calcium sulfate in the form of primary gypsum is confined to pond no.3. The latter $\left(\sim 1.403 \mathrm{~km}^{2}\right)$ represents a perennial, shallow, sub-aqueous, semi-closed basin, wherein the seasonal water level is governed mainly by the evaporation rate. Its extent, depth and configuration, enhances brine flow from west to east (Fig. 1), generating a horizontal salinity gradient. The brine column is about $2.30 \mathrm{~m}$ deep with an average salinity of about 231.1g/l (Metwally, 2002); the brine entering from pond no. 2 has a salinity approaching the saturation of primary gypsum $(130 \pm 20 \mathrm{~g} / \mathrm{l})$, and salinity increases gradually eastward to about $260 \mathrm{~g} / \mathrm{l}$ at the eastern end of the pond (close to pond no.4).

\section{MATERIALS AND METHODS}

During the past few decades, a considerable amount of gypsum has accumulated along the banks (up to $3 \mathrm{~m}$ wide $\mathrm{x}$ $1.5 \mathrm{~m}$ thick) of pond no.3 (Fig. 2). Sampling was carried out during the spring of 2006, above and below the temporarily brine on both northern and southern banks of pond no. 3 at regular intervals, from west to east, in order to register the direct effect of both salinity gradient throughout the pond and wind action on the growth of the gypsum crystals. Five brine samples representing the expected lateral salinity variation were collected. In addition, three bottom sediments, covering the entire bottom surface of the pond, and a sample of recently precipitated gypsum from the northwestern portion of the pond, representing the region of lowest salinity and minimal wind effect, were collected.

Gypsum samples were impregnated by epofix and left to dry and consolidate. Large $(7.5 \times 5 \mathrm{~cm})$ thin sections were prepared and studied with a polarizing microscope. Representative gypsum samples were then coated by gold and examined using a SEM (model Philips XL 30). Representative bulk samples were chemically investigated using X-Ray Fluorescence (XRF). The analyses were carried out by a wavelength- dispersive spectrometer (Axios PANalytical 2005), housed at National Research Centre, Dokki, Cairo. Gypsum standards (GYP-A and

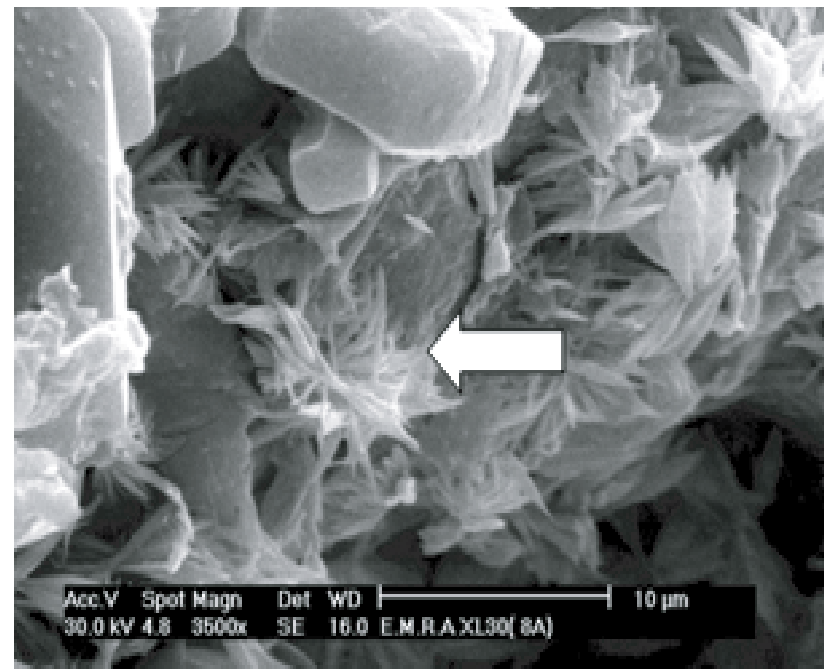

FIGURE 4 $\quad$ SEM micrograph showing fibrous glauberite crystals (white arrow).

GYP-C) were used in calibration process.

\section{FACIES DESCRIPTION}

In terms of fabric, texture and crystal morphology and size, the studied primary gypsum is classified into two main facies: a) massive selenite, and b) laminated gypsum. The latter is subdivided into two subfacies, namely, laminated grass-like selenite and microbialite (stromatolite).

\section{Massive selenite}

This facies is mainly composed of clusters of upwardgrowing selenite crystals of various crystal sizes (2 $-12 \mathrm{~cm}$ ) and growth fabric patterns (Figs. 3a \& 3b). Clusters are formed of single and twinned crystals along (100), with upward pointing re-entrant angle. Based on morphology and style arrangement of sub-parallel gypsum crystals, different fabrics may be distinguished (e.g. Hardie and Eugster, 1971; Schreiber, 1978). For example, the clustering of twinned crystals (Fig. 3a), characterized by an acute twin angle, exhibits in cross section (perpendicular to the twin plane) a radial pattern around a cavity (Fig. $3 c)$. Such structure either formed around a stick or a bulge "bubble" in the mats (before it was encrusted) that lithified due to gypsum growth (B. C. Schreiber, pers. commun., 2012). Commonly, multi-twin stacks may develop either simultaneously or subsequently, giving rise to a competent, displacement, growth nature.

Upward-growing crystals that exhibit a palmate pattern (fanning clusters) is yet another common growth pattern (cf. Fig. 3b). The (100) twin plane is commonly the nucleus of such a fabric, and the curved parts of each crystal are 
developed by regular zones of growing (120) prism faces (Schreiber, 1978). However, the palmate structure may develop by splitting individual members of the twin stacks of the crystals that have obtuse re-entrants (e.g. Shearman and Ortí Cabo, 1976; Ortí Cabo and Shearman, 1977; Schreiber, 1978). As these gypsum crystals grow outward and upward, successive split segments may develop quasi-triangular or polygonal cross-section outlines. The spaces created by splitting are commonly filled by either clastic substances or in situ skeletal, broken and lenticular gypsum. Upward curvature, sutured ends and thickening of the growing selenite crystals are conspicuous features of the selenite crystals. Hardie and Eugster (1971) attributed such upward arcing of selenite to the thickening of an individual crystal growing perpendicular to the bedding.

In general, the gypsum crystals exhibits several colors, varying from colorless with a pearly luster to green, black, purple, brown or even deep grey. Such coloration is attributed to the bacterial assemblages contained within the gypsum crystals (Schreiber and El Tabakh, 2000; Panieri et al., 2008; 2010; Ali-Bik et al., 2011). Based on FTIR data, Ali-Bik et al. (2011) inferred the relative abundance of intercalated cyanobacterial mats within the gypsum colored zones as: green $>$ black $>$ brown $>$ white. They reflect the signature of the prevailed vertical redox conditions during the continuous growth of gypsum crystals and the seasonal fluctuation of brine salinity (AliBik et al., 2011).

For example, green and purple colors represent photosynthetic bacterial forms, filamentous and coccoidal, respectively (Schreiber and El Tabakh, 2000), indicating oxidizing conditions, in contrast to black crystals near the bottom of some dark beds due to the predominance of nonphotosynthetic, sulfate-reducing bacteria. The most characteristic feature of this facies is the continuous crystal growth that gives the selenite its massive aspect with little macroscopically discernible bedding. According to Ciarapica et al. (1985), the observed structure is nearly the
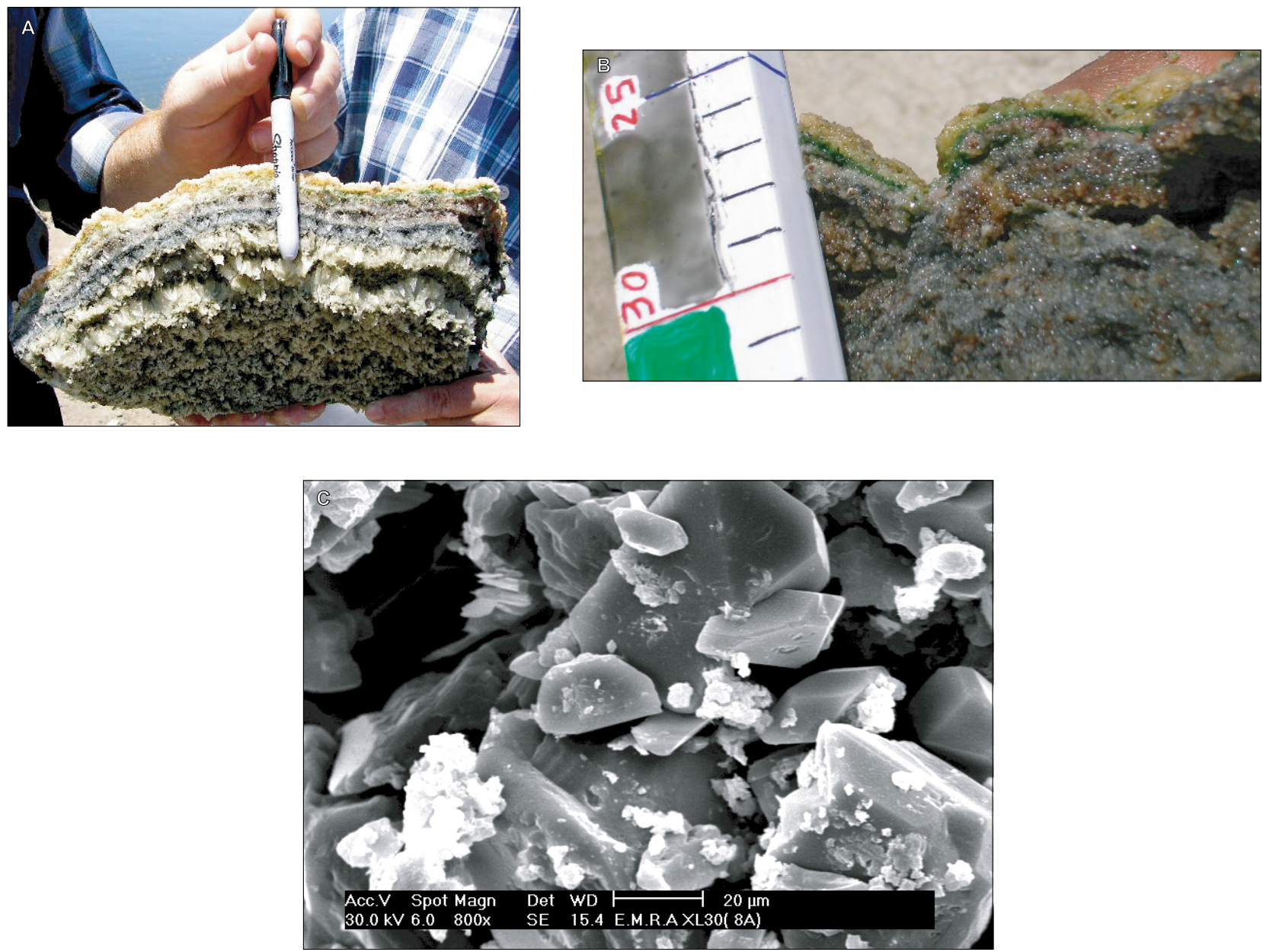

FIGURE 5 A) Laminated selenite (grass-like subfacies). B) Fine grained gypsum microbialite (stromatolite) subfacies. Scale is in $\mathrm{cm}$. C) SEM micrograph of fine lenticular gypsum crystals embedded in microbial biofilm (gypsum microbialite). 
same as the idiotopic massive bank type.

Under the polarizing microscope, the selenite crystals are relatively large $(\sim 4 \mathrm{~cm})$ and have interlocking boundaries. They form clusters of mainly sub-vertically arranged crystals. The crystals exhibit perfect crystal faces and distinct cleavages with the intercalation of thin gypsified algal-mat filaments. Similar filamentous bacterial forms were identified in upper Miocene (Messinian) primary gypsum in Italy (Panieri et al., 2008; 2010).

\section{Laminated gypsum}

This facies exhibits conspicuous lamination and varies from rhythmically laminated grass-like selenite to microbialite (stromatolite) subfacies. In contrast to the selenite layers that indicate periods of gypsum saturation (spring and summer), the rhythmic darker lamellae imply a flourishing bacterial and algal population during the winter wet seasons. Thus, as long as the salinity is lower than the gypsum saturation limit, the development of carbonate patches and fibrous glauberite crystals between gypsum lamellae is expected in intimate association with the bacterial mats (Fig. 4).

\section{Grass-like selenite}

Macroscopically, the grass-like subfacies exhibits successive gypsum lamellae (up to $1 \mathrm{~cm}$ thick) of various colors, i.e. white, brown, green, buff and black, depending on the prevailing bacterial communities. Thin gypsified algal mats and dark microcrystalline veneers of clay and minute fragmented gypsum grains separate the successive lamellae (Fig. 5a). However, the considered variety could be classified as rhythmic primary gypsum (Carozzi, 1960), laminas and beds (Ciarapica et al., 1985) or a grass-like type (Babel, 2005; Becker, 2005 and many others). Under the polarizing microscope, the successive selenite llamellae are of planar contacts and comparable size. Each selenite llamella is composed of twinned (V-shape) crystals and is covered by a thin veneer of gypsifiedalgal mats that acted as a substratum for the next growing selenite llamella during the gypsum saturation seasons (spring and summer).

\section{Gypsum microbialite (stromatolite)}

This is the microcrystalline laminated gypsum subfacies with vertically stratified colored zones (white, green, brown and black) of few $\mathrm{mm}$ to $\sim 1 \mathrm{~cm}$ thick. It exhibits characteristic doming and crenulation (Fig. 5b), due to combined effects of buckling of the growing gypsum crystals and the action of accumulated biogas (methane) beneath the algal mats, giving rise to a stromatolitic structure (Krumbein, 1983). In general, the considered subfacies exhibits a marked porosity and well established fenestral structure and could be considered as gypsum microbialite.
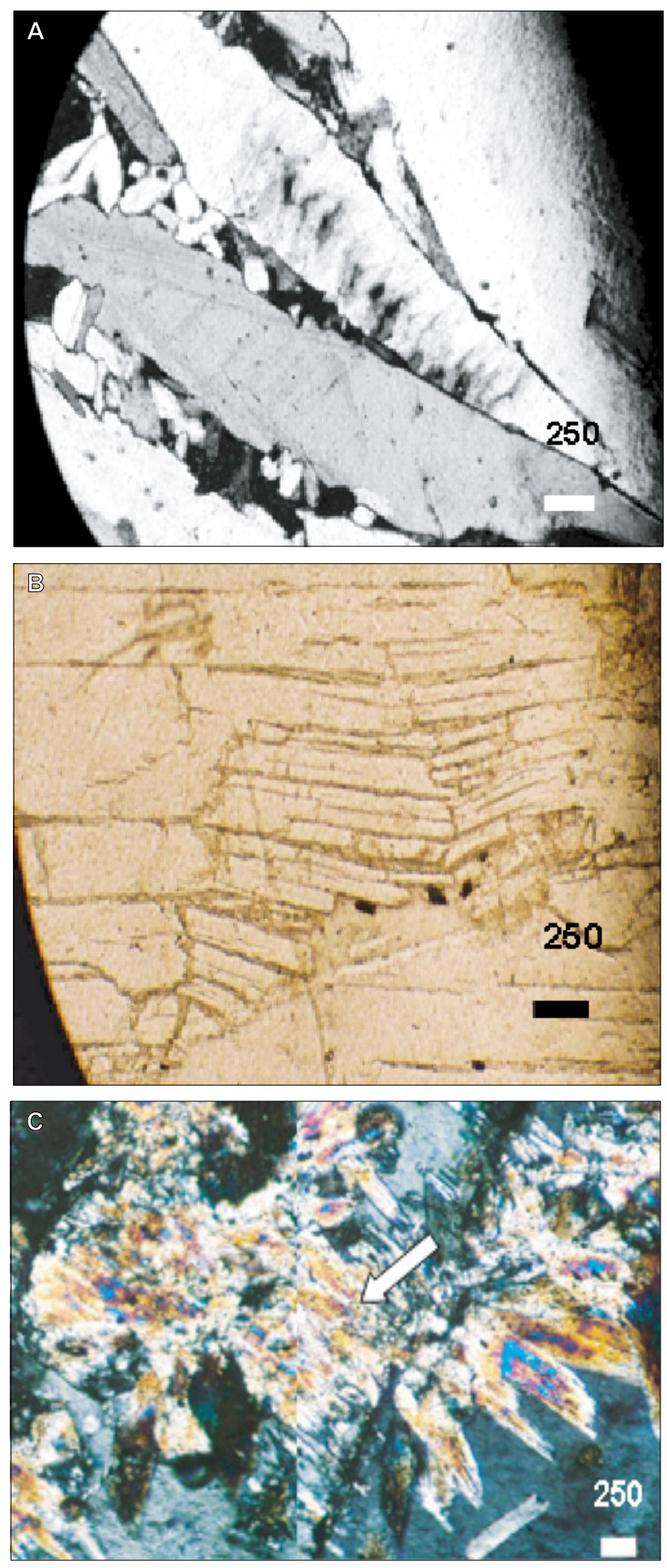

FIGURE 6 A) A selenite crystal exhibiting undulose extinction in response to a slight deformation. Crossed-polarized light. Scale Bar is $250 \mu \mathrm{m}$. B) Disintegration and cracking of a selenite crystal. Plane -polarized light. Scale Bar is $250 \mu \mathrm{m}$. C) Alteration of gypsum to anhydrite (white arrow). Crossed polarized light. Scale Bar is $250 \mu \mathrm{m}$. 
A gypsum microbialite is an organo-sedimentary deposit, formed by the interaction of a microbial community (Babel, 2005; Babel et al., 2011). Under the polarizing microscope, and compared to the other petrographic types, gypsum crystals of this variety are finer in size. It exhibits characteristic bedding, with the development of thin streaks of algal mats and carbonate patches between gypsum lamellae. Characteristic lenticels gypsum crystals $(<1 \mathrm{~mm}$ size) are recorded (Fig. $5 \mathrm{c})$ in intimate association with the cyanobacterial mats.

In fact, the observed organic lamination with different colorations and grain- size gradation reflects on one hand the prevailing oxidation/reduction conditions during gypsum crystallization and then the seasonal variation in brine concentration on the other hand. The role of bacterial mats in mineralization and development of various gypsum types are discussed in detail by Ali-Bik et al. (2011 and references therein). In general, these microorganisms and their metabolism have effective role in i) building organo-sedimentary outcrops (microbilaite and laminated stromatolite), ii) biogenic mineralization by regulating the physico-chemical conditions on a micro-scale; and iii) shaping crystal morphology and mineral texture. Thus, the development of lenticular gypsum morphology in the present example ( $c f$. Fig. 5c) is attributed to metabolic action of cyanobacteria (Ali-Bik et al., 2011). According to Cody and Cody (1989) the development of lenticular gypsum morphology is attributed to the interaction of certain organic molecules, such as enzyme $\alpha$-analyze which act as crystallization inhibitor by decreasing the growth gypsum crystals in c [001] direction and inducing nucleation of d [101] Montmartre twins.
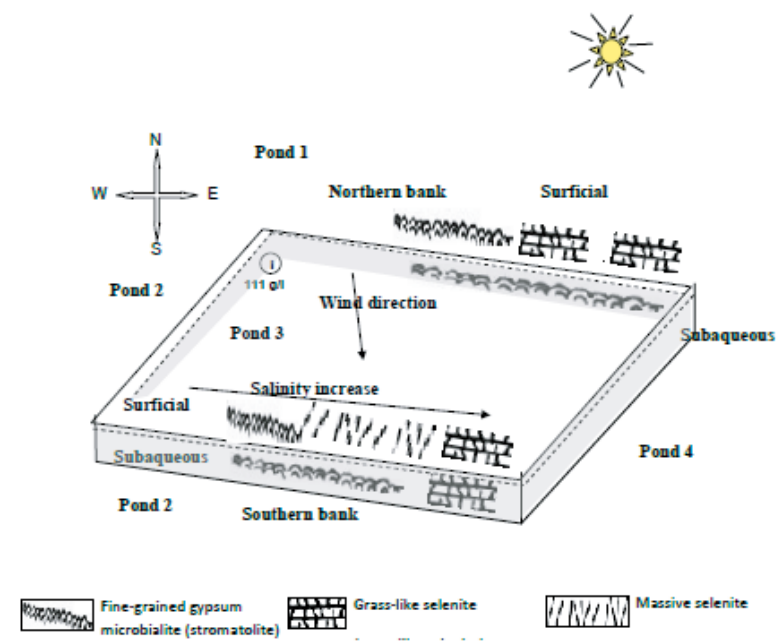

FIGURE 7 A sketch showing the distribution of gypsum facies in pond no. 3, above and below the temporarily brine level.

\section{DIAGENETIC ALTERATION}

The diagenetic impact on sediments is generally enhanced over time. However, in the studied recent gypsum deposits slight post-depositional changes are clearly apparent. Destruction of gypsum mounds, methane emission (due to decay of organic matter) at the western side of the pond (close to pond no.2) and dissolution of gypsum crystals are reported. Different generations of gypsum precipitation that imply varied growth rates under fluctuating physio-chemical conditions have been observed. Accumulations of the new gypsum precipitation accompanied by pressure-overgrowth may affect the earlyformed gypsum crystals leading to undulose extinction (Fig. 6a) and recrystallization. Deformation may also lead to cracking and disintegration of selenite crystals (Fig. 6b) or may proceed to complete fragmentation with changes in optical continuity of the deformed crystal.

Recrystallization of subaqueous primary gypsum might occur in response to pressure overgrowth, temperature rise and the fluctuation of brine composition and saturation level. As a resultant, the smaller fragmented gypsum crystals may transform to hemihydrite, bassanite or even to anhydrite (Fig. 6c). The latter phase exhibits higher interference colors than gypsum. Alteration on the peripheries of the gypsum crystals in response to dissolution is also recorded.

\section{DISTRIBUTION OF FACIES}

The distribution of gypsum facies in pond no. 3 is illustrated in Figure 7, whereas close to pond no.2, the outcrop is relatively soft with an offensive odor due to the decay of organic matter. The thickness of accumulated gypsum deposits at the bottom of pond no.3 was about $10 \mathrm{~cm}$ as checked through dragging and coring. They form a dark-grey, friable crust and more or less resemble the microbialite subfacies. Both of laminated gypsum subfacies (microbialite and grass-like selenite) are distributed along the northern and the southern banks of pond 3. On the southern bank, the massive selenite facies is reported, and commonly lays in between the two common subfacies (microbialite and grass-like selenite).

\section{CHEMICAL COMPOSITION}

\section{Water chemistry}

The chemical composition of Lake Quaroun water and of concentration pond no.3 (averages for 8 months from January to August, 1999), as well as seawater as given by Ali and El Sheikh (2004) are summarized in Table 1. Other parameters, including $\mathrm{pH}$, electrical conductivity and total 
TABLE 1 Hydrochemistry of Lake Quaroun water and pond no. 3 (averages for 8 months from January to August, 1999), as well as sea water, as given by Ali and El Sheikh (2004). All values are given in g/l.

\begin{tabular}{|l|l|l|l|}
\hline & Seawater & Lake Quaroun & Pond no. 3 \\
\hline $\mathbf{N a}$ & 10.56 & 9.89 & 73.10 \\
\hline $\mathbf{C a}$ & 0.40 & 0.48 & 0.38 \\
\hline $\mathbf{M g}$ & 1.27 & 1.31 & 8.70 \\
\hline $\mathbf{K}$ & 0.38 & 0.22 & 0.79 \\
\hline $\mathbf{C l}$ & 18.98 & 12.74 & 96.30 \\
\hline $\mathbf{S O}_{4}$ & 2.56 & 9.41 & 57.30 \\
\hline $\mathbf{H C O}_{3}$ & 0.14 & 0.30 & 0.64 \\
\hline $\begin{array}{l}\text { Salinity } \\
\text { (TDS) }\end{array}$ & 34.40 & 34.30 & 244.30 \\
\hline
\end{tabular}

dissolved salts of the collected brine samples are given in Table 2.

In terms of Total Dissolved Salts (TDS), Lake Quaroun and seawater are more or less comparable. In comparison with seawater, Lake Quaroun water is conspicuously enriched in sulfate, bicarbonate and to lesser extent in calcium. However, the concentrations of $\mathrm{K}$ and $\mathrm{Cl}$ are low in Lake Quaroun water.

Regarding the abundances of cations and anions in the Lake Quaroun saline water, the following distribution is observed: $\mathrm{Na}>\mathrm{Mg}>\mathrm{Ca}>\mathrm{K}$ and $\mathrm{Cl}>\mathrm{SO} 4>\mathrm{HCO} 3$. A similar ion distribution is traceable in concentration pond no.3 (Table 1). TDS in the collected brine samples (1S $6 \mathrm{~S}$ ) as shown in Table 2 vary from 110.55 to $192.36 \mathrm{~g} / \mathrm{l}$. The lowest value represents the collected brine from the inlet (close to the pond no.2) of pond no.3; in general, the TDS increased in eastward direction. Electric conductivity ranges from 1424 to $2222 \mu \mathrm{S}$, while $\mathrm{pH}$ values fluctuate between 7.86 and 8.19 .

\section{Whole-rock chemistry}

Bulk chemical composition of the studied gypsum and sediments and their calculated normative components are given in Table I, Electronic Appendix available at www. geologica-acta.com. Of the main constituents (gypsumcombined water, $\mathrm{SO} 3$ and $\mathrm{CaO}$ ), the massive selenite facies exhibits the highest contents, i.e. highest purity.

In term of major and trace element contents, both grasslike selenite and microbialite subfacies are more or less comparable as they contain small amount of clay fraction (aggregates). Compared to the massive selenite facies, both grass-like selenite and gypsum microbialite subfacies are depleted in $\mathrm{Sr}$ and $\mathrm{Co}$ contents; while $\mathrm{Ba}$ and $\mathrm{Y}$ are enriched.

Regarding the normative components, the massive selenite facies is more homogenous, as expected, exhibiting
TABLE 2 Total dissolved solids (TDS), $\mathrm{pH}$ and electrical conductivity of the collected brine samples (April 2006) from pond no. 3

\begin{tabular}{|l|c|c|cc|}
\hline $\begin{array}{l}\text { Sample } \\
\text { No. }\end{array}$ & TDS & pH & \multicolumn{2}{|c|}{ EC } \\
\hline $1 \mathrm{~S}$ & 110.55 & 8.11 & 1424 & $\mu \mathrm{s}$ \\
\hline $3 \mathrm{~S}$ & 170.85 & 8.19 & 2220 & $\mu \mathrm{s}$ \\
\hline $4 \mathrm{~S}$ & 192.36 & 7.86 & 2222 & $\mu \mathrm{s}$ \\
\hline $5 \mathrm{~S}$ & 150.15 & 8.14 & 1939 & $\mu \mathrm{s}$ \\
\hline $6 \mathrm{~S}$ & 161.00 & 8.10 & 2074 & $\mu \mathrm{s}$ \\
\hline
\end{tabular}

the highest gypsum and anhydrite content (up to $95 \% \mathrm{wt}$.). In the grass-like selenite and microbialite subfacies of the southern and northern banks, normative gypsum and anhydrite content is ranging from 93 to $86 \%$ by weight. The recently precipitated gypsum contains about $90 \%$ normative gypsum and anhydrite by weight. Turning to bottom sediments, the sample no.3B (high-salinity zone) contains about $84 \%$ normative gypsum and the sample no.1B (low-salinity) contains the highest amount of clay fraction (up to $26 \%$ by weight).

\section{DISCUSSION}

Enhancing the wind-action effect, the gypsum outcrop on the southern bank is more mature in terms of crystal size and degree of lithification, compared to that of the northern side. Similarly, the salinity gradients change eastwardly, and the sediment maturity has obviously increased in the same direction also. Hence, at the northwest corner (close to ponds nos. 1 and 2), no gypsum mounds have been recorded; instead, newly formed, very fine gypsum crystals have been visually monitored (at the time of sampling), indicating a fast nucleation rate. These new gypsum crystals will more readily dissolve than accumulate as gypsum mounds. In general, the dissolution and subsequent destruction of incipient gypsum mounds are more common in the western part of the pond, where the lowest salinity values are expected (about $111 \mathrm{~g} / \mathrm{l}$ at the time of sampling). Meanwhile, distribution of selenite varieties (both massive and laminated grass-like) is confined to the higher salinity area, in comparison with the fine-grained gypsum microbialitic (stromatolitic) type.

\section{Modeling of pond no.3}

In general, the varied evaporite facies in a particular deposition basin reflect the characteristics of their respective stratified brine zones (e.g. Ortí Cabo et al., 1984a; 1984b; Peryt, 1996; Babel, 2004; 2007; Schreiber et al., 2007). Regarding pond no. 3 as a gypsum deposition basin, its main features argue in favor of both the selenite shoal and monomictic selenite pan models of Babel (2004). The used terminology in the proposed models follows mainly Babel (2004 and references therein) and 
Schreiber et al. (2007):

Monomictic: a lake, which is stratified only in one season (winter or summer) of the year and becomes homogeneous through entire mixing in other seasons. Polymictic: a lake, with frequent periods of mixing per year.

Epilimnion: an upper layer of a seasonally stratified water body.

Hypolimnion: represents the lower layer of a seasonally stratified water body.

Pycnocline: the boundary between two different brines (low and high salinities).

In both shoal and monomictic pans models, gypsum microbialite and selenite reflect different salinity environments, whereas the latter is confined only to the relatively higher salinity brines and more resistant to dissolution processes (e.g. Ortí Cabo et al., 1984a; 1984b; Babel, 2004). In the selenite shoal model, the salinity gradient is horizontal; hence, the selenite crust on an evaporite shoal is thin and more susceptible to dissolution. In contrast, the salinity gradient is vertical in the monomictic pan model during the wet seasons; hence, the level of the pycnocline is crucial, whereas the selenite growth is mainly related to evaporation of the epilimnion and occasionally to interaction with the hypolimnion. The latter case is maintained in shallow and large pans when the hypolimnion is partially exposed to the surface, and hence, to evaporation by the action of strong unidirectional wind. Steady strong wind acting in this way, may lead to complete mixing (polymictic condition).

Regarding the water of Lake Quaroun ( $3.5 \%$ salts), the gypsum saturation level is approached by reducing the water budget via evaporation to about $20 \%$ of its original volume (Ali et al., 2007). Concentration pond no.3, as a basin of gypsum deposition, experienced two evolutionary stages: a) the first stage extended from the onset of gypsum saturation until 1995, where the pond acted as a natural gypsum precipitation basin, and b) the second stage continued from 1995 to the present, during which time the pond management policy was adopted. The aim of this process was to maximize the productivity of thenardite (Na2SO4) and edible $\mathrm{NaCl}$ by preventing any salt precipitation in pond no. 4 by controlling the concentration
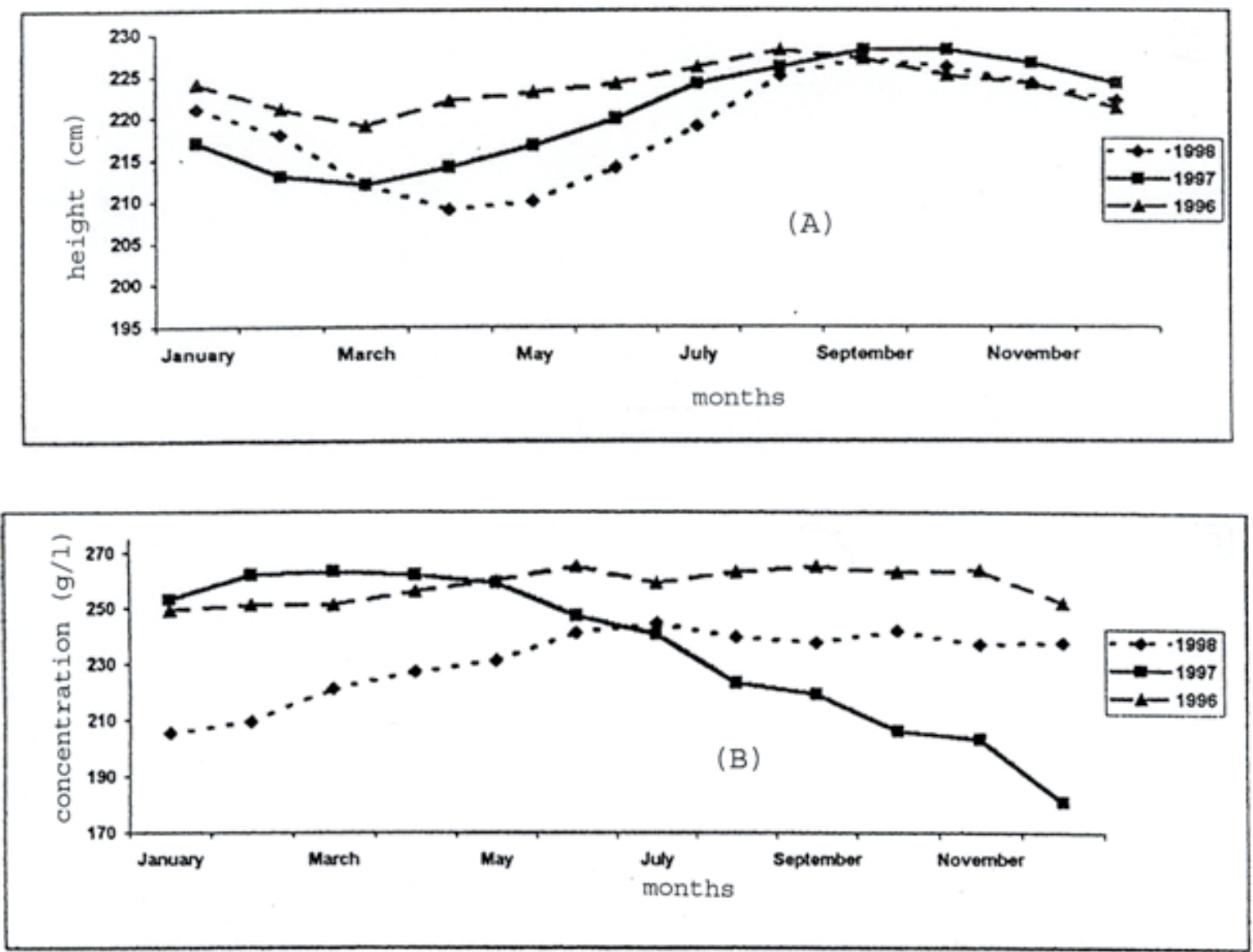

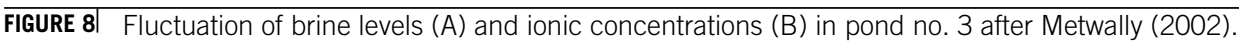


levels and salinities of the other ponds.

The pond management process of Lake Quaroun involves two complementary steps. The first concerns decreasing the concentration of $\mathrm{Ca}$ ions in ponds nos. 3 and 4 by enhancing the aragonite precipitation in pond no.2 using specific types of algae (Wali et al., 1997). In the second step, a brine-mixing technique (back drift) is employed by pushing the hyper-saline brine from the end of pond no. 4 back to pond no. 3 to maintain the salinity of pond no. 4 as planned.

Metwally (2002) recorded the fluctuation of brine levels and subsequent concentrations in pond no. 3 for three successive years (1996-1998), and he noted a substantial fluctuation in brine level and subsequent seasonal concentrations during the year 1998 compared to those of years 1996 and 1997 (Fig. 8). In winter season of 1998, pond no.3 received excess amounts of low-salinity water (under-saturated with respect to gypsum) from Lake Quaroun through pond no.2, representing the wet season of the perennial basin. During the dry season (spring and summer), there was a conspicuous increase in the reported concentration, providing favorable conditions for gypsum precipitation. According to Ali et al. (2007 and references therein) the biota of pond no. 3 include algae, diatoms and brine shrimps; the collected algae from pond no. 3 were identified as cyanobacteria and chlorophyta (Ali-Bik et al., 2011).

The relatively shallow brine depth $(2.30 \mathrm{~m})$ of pond 3 and the surface salinity gradient towards pond no. 4 argue in favor of a selenite shoal model, except for the region close to pond no.4. Hence, the relatively persistent brine budget near pond no.4 (higher salinity zone), provides the opportunity for pycnocline development (stratification) in this part of the pond during wet seasons when low salinity influx is supplied from pond no.2 (cf. Fig. 8).

However, the western portion of pond no.3, acts as a low-salinity zone, following either the selenite shoal or the monomictic pan models. Hence, fine-grained gypsum microbialite with a thin selenite crust is expected to be developed during the dry seasons of such environments (e.g. Ortí Cabo et al., 1984a; 1984b; Babel, 2004). The area (I) at the northwestern part of the pond (Fig. 7) is characterized by the lowest degree of salinity and minimal wind action; hence, dissolution of recently formed gypsum is typical, i.e., the opportunity to build gypsum mounds is greatly decreased. Generally, during wet seasons (dilution process from pond 2), dissolution of the pre-existing gypsum is common.

In contrast, the eastern portion of pond no.3, close to pond no.4, is characterized by relatively higher salinity environment; hence, the development of selenite, following any of the proposed models is the case. In both models, this zone is characterized by continual growth (syntaxial) of selenite due to permanent brine saturation with gypsum (Babel, 2004). In this manner, pond no. 3 acts as a shallowbrine selenite pan.

Regarding the evolution of brines in pond no.3, two stages are distinguished:

\section{From the onset of gypsum saturation until 1995:}

During this period, pond no.3 acted as a natural deposition basin for selenite, more or less simulating the entire process of selenite deposition in the selenite shoal model of Babel (2004). In this situation, the pond received from time to time (wet seasons) the inflow of brine from pond no.2, with a salinity of about $130 \mathrm{~g} / \mathrm{l}$. Then, the brine flowed towards pond no.4 with a gradual increase of salinity (up to about $260 \pm 20 \mathrm{~g} / \mathrm{l}$ ), due to evaporation (dry seasons) and subsequent gypsum precipitation. In general, the precipitation of gypsum begins at a salinity of about $150 \%$.

Hence, the distribution of gypsum facies in the pond reflects the lateral variation in the salinity environments. Fine-grained gypsum microbialite subfacies is confined to the low-salinity zone (western portion of the pond) and selenite deposition to the higher salinity environment.

\section{From 1995 to the present:}

Pond management policy and repeated dilution of the pond turned it into a true shallow-brine selenite pan, with development of a seasonal pycnocline and stratification (particularly at the eastern end, close to pond no.4). In such an environment, laminated selenite (grass-like type) may develop. For this to happen, the mixing (back-drift) process, i.e., pumping of the heavier hyper-saline brine with salinity that exceeds the upper salinity limit of gypsum crystallization ( $>320 \mathrm{~g} / \mathrm{l}$ salinity) from pond no.4 to the lower (hypolimnion) zone of pond no.3, is crucial. Thus, the pre-existing selenite (pre-management) will be partially or totally dissolved by the hyper-saline brine of bond no.4.

In addition, the conspicuous deficiency of $\mathrm{Ca}$ ions in pond no. 3 due to pond management greatly diminishes the opportunity of developing large selenite crystals, as it is a matter of concentration rather than salinity. Accordingly, the reported massive selenite facies represents an earlier gypsum outcrop that developed in conditions of high salinity (hypolimnion zone) in presence of excess of aqueous $\mathrm{Ca}$ and absence of mixing, i.e., during pre pondmanagement. Simulation of such conditions in nature may give rise to giant and saber gypsum facies - as examples 
- of northern Carpathian Foredeep (Babel, 2005). CONCLUSIONS

From a geologic point of view, the clay fraction that settled and salts precipitated throughout the concentration ponds at EMISAL (nos. 1, 2 and 3) represent a thin sedimentary succession. Clays occur at the base of the section (pond no.1), followed upward by calcium carbonates (ponds nos.1 and 2) and topped by primary gypsum in pond no.3. In the latter, gypsum precipitates formed with variable fabrics, crystal morphologies and sizes on the floor and along the banks. Accordingly, the primary gypsum is classified into two main facies: a) massive selenite, and b) laminated gypsum. The second facies is subdivided into two subfacies, namely grass-like selenite and fine-grained gypsum microbialite (stromatolite). The massive selenite facies is composed of clusters of single and twinned crystals along (100), with upward pointing re-entrant angle. The laminated gypsum facies exhibits conspicuous bedding and varied from rhythmically laminated grasslike selenite to microbialite (stromatolite). The variation from massive selenite to laminated-gypsum facies implies fluctuation in lateral and vertical salinity profiles, seasonal brine concentrations and wind action.

Many signs of diagenetic modification are apparent including: a) dissolution, b) slight to moderate crystal deformation and finally, c) recrystallization, including the dehydration of primary gypsum. Chemically, the massive selenite facies exhibits the highest purity; both grass-like selenite and fine-grained gypsum microbialite subfacies are more or less comparable.

Modeling of pond no. 3 should be considered in the light of the evolution history of the brine (pre- and postmanagement of the pond). During the first stage, the pond acted as a natural basin of selenite crystallization (selenite-shoal model), and the distribution of gypsum facies in the pond reflects the laterally varying salinity. The fine-grained gypsum microbialite subfacies is confined to the low-salinity zone (western portion of pond no.3) and selenite to the higher salinity environment. Dissolution and fragmentation of the selenite crust at the western portion of the pond (low-salinity area) is common in the wet seasons. Meanwhile, the relatively higher salinity environment in the eastern portion, close to pond no.4 (higher salinity zone) is characterized by continual growth of selenite (syntaxial growth) with little dissolution signature.

After adopting pond-management policy and repeated dilution, the pond has been turned to a true shallowbrine selenite pan. Hence, due to different gradients of $\mathrm{Ca}$ concentration, the laminated grass-like selenite subfacies may develop at higher salinity zones instead of massive selenite facies, i.e., it is the matter of continuous concentration rather than salinity.

Therefore, the pre-existing (pre-management) large selenite crystals will partially or totally dissolve during the back-drift processes due to contrast with the hyper-saline brines (> 320g/l salinity) of pond no.4. Accordingly, the reported, massive selenite facies might represent an earlier gypsum outcrop that developed in the presence of excess $\mathrm{Ca}$ ions (pre-management) perhaps under deeper water levels and without subsequent dilution processes.

\section{ACKNOWLEDGMENTS}

We would like to express our gratitude to R. El Sheikh and other colleagues at EMISAL for their help during the field work and sampling. We are indebted to M. Babel, B.C. Schreiber, E.S. Montero and J.P. Rodríguez-Aranda for their constructive comments and suggestions which improved the manuscript. Our thanks go to F. R. Ettensohn for reviewing the initial draft of the manuscript and improving the English style. We would like to thank R. Atanassova and an anonymous reviewer for their constructive comments and criticism. Also, we are grateful to the editorial board of the journal for their help in improving the English style of the paper.

\section{REFERENCES}

Ali, Y. A., El Sheikh, R. M., 2004. Brine geochemistry of the southern coast of lake Quaroun water and nearly saline and hypersaline solar ponds, Fayium-Egypt. 6th Int. Conf. Geochemistry, Alexandria Univ. Egypt, pp 71-90.

Ali, Y. A., Dardir, A. A., El Sheikh, R. M., 2007. Parameters affecting evaporite deposition in artificial saline and hyper saline ponds brines. 2 nd Conf., NRC. Cairo, Egypt.

Ali-Bik, M.W., Metwally, H. I. M., Kamel, M. G., Wali, A. M. A., 2011. Gypsum and dolomite biomineralization in endoevaporitic microbial niche, EMISAL, Fayium, Egypt. Environ Earth Sci, 62, 151-159.

Al-Kordy, A.T.M., 2003. Environmental impact and development of Quaroun lake as salt reservoir. Unpublished M.Sc Thesis, Faculty of Science, Menoufia University, Egypt. 101pp.

Babel, M., 2004. Models for evaporites, selenite and gypsum microbialite deposition in ancient saline basins. Acta Geol. Polonica, 54, No.2, 219-249.

Babel, M., 2005. Selenite-gypsum microbialite facies and sedimentary evolution of the Badenian evaporate basin of the northern Carpathian Foredeep. Acta Geologica Polonica, 55, No.2, 187-210.

Babel, M., 2007. Depositional environments of a salina-type evaporite basin recorded in the Badenian gypsum facies in northern Carpathian Foredeep. In: Schreiber, B. C., Lugli, S. and Babel, M. (Eds.) Evaporites through Space and Time. Geological Society, London, Special Publications, 285, 107142. 
Babel, M., Olszewska-Nejbert, D., Bogucki, A., 2011. Gypsum microbialite domes shaped by brine currents from Badenian evaporites of western Ukraine. In: J. Reitner et al. (Eds.) Adavances in stromatolite geobiology, lecture notes in Earth Sciences. Springer-Verlag Berlin Heidelberg. 131, 297-320.

Beadnell, H.J.I., 1905. The topography and geology of Fayum Province of Egypt. Egypt. Surv. Dept., Cairo, 101pp.

Becker, A., 2005. Facies development of the Badenian (Middle Miocene) gypsum deposits in the Raclawice area (Miechow Uplands, Southern Poland. Annals Societatis geologorum Poloniae, 75, 111-120.

Carozzi, A., 1960. Microscopic sedimentary petrography. John Wiley, Inc., New York, 485 pp.

Ciarapica, G., Passeri, L., Schreiber, C. B., 1985. Una proposta di classificazione Delle evaporiti solfatiche. Geologica Rom., 24, 219-232.

Cody, A. M., Cody, R. D., 1988. Gypsum nucleation and crystal morphology in analogy saline terrestrial environments. J. Sed. Petrol. 58/2, 247-255.

Cody, A. M., Cody, R. D., 1989. Evidence for micro-biological induction of $\{101\}$ Montmartre twinning of gypsum (CaSO4. 2H2O). Jour. Crystal Growth, 98, 721-730.

Cornée, A., Dickman, M., Busson, G., 1992. Laminated cyanobacterial mats in sediments of solar salt works- some sedimentological implications. Sedimentology, 39, 599-612.

DSS Engineers INC Coopers and Lybrand CRS International, 1979. Engineering/Economic Feasibility Lake Qaroun, Final Report, 120pp.

Embabi, N. S., 2004. The geomorphology of Egypt. Landforms evolution. Vol. I. The Nile Valley and the Western Desert. Egyptian Geographical Soc., Spec. Pub., Cairo. 447 pp.

Hardie, L. A., Eugster, H. P., 1971. The depositional environment of marine evaporites: A case for shallow, clastic accumulation. Sedimentology, 16, 187-220.

Kasprzyk, A., 2003. Sedimentological and diagenetic patterns of anhydrite deposits in the Badenian evaporate basin of the Carpathian fordeep, Southern Polan. Sed. Geol., 158, 167-194.

Krumbein, W.E., 1983. Stromatolites, the Challenge of a term in Space and Time. Precambrian Res. 20, 493- 531.

Metwally, H. I., 2002. Mineralogical and chemical characteristics of the precipitates and brines from solar concentration ponds and its industrial applications, Lake Quaroun, EMISAL (case study). Unpublished Ph.D. Thesis, Fac. Sci. Cairo University, Egypt. 90pp.

Ortí Cabo, F., Shearman, D.J. 1977. Estructuras y fábricas deposicionales en las evaporitas del Mioceno superior (Messiniense) de San Miguel de Salinas (Alicante, España). Inst. Invest. Geol., Dip. Prov. Barcelona, 32, 5-54.

Ortí Cabo, F., Pueyo Mur, J. J., Geisler-Cussey, D., Dulau, N., 1984a. Evaporitic sedimentation in the coastal salinas of Santa Pola (Alicante, Spain). Rev. Inv. Geol., 38/39,169-220. Ortí Cabo, F., Pueyo Mur, J. J., Truc, G., 1984b. Las salinas maritimas de Santa Pola (Alicante, España). Breve introducción al estudio de un medio natural controlado de sedimentación evaporítica somera. Rev. Inv. Geol., 38/39,9-29.

Panieri, G., Lugli, S., Manzi, V., Palinska, K.A., Roveri,M., 2008. Microbial communities in Messinian evaporite deposits of the Vena del Gesso (northern Apennines, Italy). Stratigraphy, 5, nos. 3-4, pp. 343-352.

Panieri, G., Lugli, S., Manzi, V., Roveri, M., Schreiber, B.C., Palinska K.A., 2010. Ribosomal RNA gene fragments from fossilized cyanobacteria identified in primary gypsum from the late Miocene, Italy. Geobiology 8, 101-111.

Peryt, T. M., 1996. Sedimentology of Badenian (Middle Miocene) gypsum in eastern Galicia, Podolia and Bukovina (West Ukraine). Sedimentology, 43, 571-588.

Peryt, T. M., 2001. Gypsum facies transition in basin-marginal evaporites: Middle Miocene (Badenian) of West Ukraine. Sedimentology, 48, 1103-1119.

Said, R., 1960. New sight on the origin of the Qattara depression. Bull. Soc. Géograph. Egypte, 33, 37-44.

Said, R., 1962. The geology of Egypt. Elsevier Pub. Co., Amsterdam, 377p.

Samy, M.S., 2000. Environmental study on Quaroun lake as a closed final disposal basin. Unpublished M. Sc. Thesis, Faculty of Engineering, Cairo University, Egypt.

Schreiber, B. C., 1978. Environments of subaqueous gypsum deposition. In: Dean, W. E., Schreiber, B. C. (Eds.), Marine evaporites. SEPM short course, Oklahoma City, 4, pp. 43-73.

Schreiber, B. C., Babel, M., Lugli, S., 2007. Introduction and overview. In: Schreiber, B. C., Lugli, S., Babel, M. (Eds.), Evaporites through Space and Time. Geological Society, London, Special Publications, 285, 1-13.

Schreiber, B. C., El Tabakh, M., 2000. Deposition and early alteration of evaporites. Sedimentology, 47, 215-238.

Shearman, D.J., Ortí Cabo, F., 1976. Upper Miocene gypsum: San Miguel de Salinas, SE Spain. Mem. Soc. Geol. Ital., 16, 327-340.

Tucker, M. E., 2001. Sedimentary petrology: an introduction to the origin of sedimentary rocks. Blackwell Science Ltd. 3ed ed. $261 \mathrm{pp}$.

Wali, A. M. A., Samy, Y. M., El Sheikh, R. M., Abdel Tawab, A. M., 1997. Aragonite development by biomineralization application to $\mathrm{Ca}$ reduction in hypersaline pond, Qaroun Lake, Egypt. Sedimentological Soc. Egypt, 5, 31-41.

Warren, J.K., 1982. The hydrological setting, occurrence and significance of gypsum in late Quaternary salt lakes in South Australia. Sedimentology, 29, 609-637.

Warren, J. K., Kendall, C.G.S.C., 1985. Comparison of sequnces formed in marine Sabkha (subaerial) and salina (subaqueas) settings-modern and ancient. Am. Assoc. Petrol. Geol. Bull., 69, 1013-1023.

White Young and Partners 1976. Exploration of salts from Lake Quaroun. Reports and miscellaneous data (internal). 100 pp.

Manuscript received June 2012;

revision accepted September 2013;

published Online October 2013. 


\section{ELECTRONIC APPENDIX}

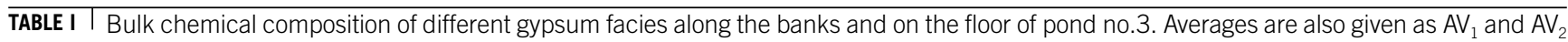

\begin{tabular}{|c|c|c|c|c|c|c|c|c|}
\hline \multirow[b]{3}{*}{ Sample No. } & \multicolumn{8}{|c|}{ Southern and northern banks } \\
\hline & \multicolumn{4}{|c|}{ Massive selenite } & \multicolumn{4}{|c|}{ Grass-like selenite } \\
\hline & $3 A$ & $4 \mathrm{~A}$ & $5 \mathrm{~A}$ & $A V_{1}$ & $6 \mathrm{~A}$ & $6 Q$ & $10 \mathrm{~A}$ & $\mathrm{AV}_{2}$ \\
\hline \multicolumn{9}{|l|}{ wt.\% } \\
\hline $\begin{array}{l}\text { Combined } \\
\mathrm{H}_{2} \mathrm{O}\left(250 \mathrm{C}^{\circ}\right)\end{array}$ & 19.11 & 19.26 & 19.11 & 19.16 & 18.74 & 17.14 & 16.36 & 17.41 \\
\hline $\mathrm{SO}_{3}$ & 44.66 & 44.68 & 44.82 & 44.72 & 43.46 & 40.14 & 41.07 & 41.56 \\
\hline $\mathrm{CaO}$ & 31.49 & 30.80 & 32.10 & 31.46 & 30.89 & 29.05 & 29.52 & 29.82 \\
\hline $\mathrm{Al}_{2} \mathrm{O}_{3}$ & 0.09 & 0.05 & 0.08 & 0.19 & 0.53 & 0.57 & 0.43 & 0.28 \\
\hline $\mathrm{Fe}_{2} \mathrm{O}_{3}$ Tot. & 0.05 & 0.04 & 0.05 & 0.14 & 0.39 & 0.43 & 0.32 & 0.20 \\
\hline $\mathrm{MgO}$ & 0.12 & 0.19 & 0.08 & 0.13 & 0.23 & 0.49 & 0.69 & 0.47 \\
\hline $\mathrm{SiO}_{2}$ & 0.45 & 0.31 & 0.34 & 0.37 & 1.36 & 3.15 & 2.45 & 2.32 \\
\hline $\mathrm{TiO}_{2}$ & ------ & ------ & ------ & ------ & ------ & 0.08 & 0.06 & 0.07 \\
\hline $\mathrm{P}_{2} \mathrm{O}_{5}$ & 0.01 & 0.01 & 0.01 & 0.01 & ------ & 0.01 & 0.02 & 0.02 \\
\hline $\mathrm{Na}$ & 0.70 & 0.45 & 0.33 & 0.49 & 0.53 & 1.28 & 1.05 & 0.95 \\
\hline K & 0.02 & 0.02 & ------ & 0.02 & 0.05 & 1.10 & 0.10 & 0.42 \\
\hline $\mathrm{Cl}$ & ------ & 0.63 & 0.24 & 0.44 & 0.95 & 2.26 & 1.44 & 1.55 \\
\hline ppm & ------ & 4678 & 4300 & 4489 & 3675 & 3473 & 4717 & 3955 \\
\hline $\mathrm{Ba}$ & ------ & 119 & 113 & 116 & 109 & 154 & 161 & 141 \\
\hline $\mathrm{Ni}$ & ------ & 49 & 67 & 58 & 38 & 60 & 65 & 54 \\
\hline $\mathrm{Rb}$ & ------ & 7 & 9 & 8 & 12 & 10 & 9 & 10 \\
\hline $\mathrm{Zn}$ & ------ & 18 & ------ & 18 & 20 & 11 & 26 & 19 \\
\hline $\mathrm{Mn}$ & ------- & 35 & 1 & 18 & 9 & 140 & 278 & 142 \\
\hline $\mathrm{Cu}$ & ------- & ------- & 10 & 10 & 46 & 14 & 28 & 29 \\
\hline $\mathrm{Br}$ & ------ & ------ & ------ & ------ & ------ & 58 & 53 & 55 \\
\hline \multicolumn{9}{|l|}{ wt.\% } \\
\hline Combined & & & & & & & & \\
\hline $\mathrm{H}_{2} \mathrm{O}\left(550 \mathrm{C}^{\circ}\right)$ & 1.89 & 1.85 & 0.83 & 1.52 & 2.03 & 2.79 & 3.75 & 2.86 \\
\hline $\begin{array}{l}\text { Moisture } \\
\left(\mathrm{H}_{2} \mathrm{O}-45 \mathrm{C}^{\circ}\right)\end{array}$ & 0.06 & 0.07 & 0.13 & 0.09 & 0.13 & 0.18 & 0.10 & 0.14 \\
\hline $\begin{array}{l}\text { L.O.I } \\
\text { Estimated }\end{array}$ & 21.60 & 22.80 & 21.40 & 21.93 & 21.90 & 22.50 & 21.80 & 22.07 \\
\hline $\mathrm{CO}_{2}$ & 0.54 & 1.62 & ------ & 1.08 & ------ & 2.39 & 1.59 & 1.99 \\
\hline
\end{tabular}

Normative wt. \%

$\begin{array}{ccccccccc}\text { Gypsum } & 91 & 92 & 91 & 91.3 & 90 & 82 & 78 & 83.3 \\ \text { Anhydrite } & 4 & 3 & 4 & 3.75 & 3 & 3.5 & 8 & 4.8 \\ & & & & & & & & \\ \text { Calcite } & 0.07 & -- & 1 & 0.5 & 0.5 & 0.5 & -- & 0.50 \\ & & & & & & & & \\ \text { Dolomite } & 0.5 & -- & 0.30 & 0.4 & 1 & 2 & -- & 1.5 \\ \text { Halite } & 0.30 & -- & 0.30 & 0.30 & 1 & 2.37 & 2.13 & \\ \text { Aggregates } & 0.6 & 0.4 & 0.47 & 0.5 & 1.69 & 4.07 & 3.45 & 3.07\end{array}$

* Estimated $\mathrm{CO}_{2}=$ L.O.I. - (Moisture + Combined $\mathrm{H}_{2} \mathrm{O}$ at $250 \mathrm{C}^{\circ}+$ Combined $\mathrm{H}_{2} \mathrm{O}$ at $550 \mathrm{C}^{\circ}$ ).

* Combined $\mathrm{H}_{2} \mathrm{O}$ at $250 \mathrm{C}^{\circ}$ denotes the crystalline water in gypsum structure.

* Combined $\mathrm{H}_{2} \mathrm{O}$ at $550 \mathrm{C}^{\circ}$ denotes the released water from clay structure.

* Normative components are calculated - mainly- according to Ragab (1967). 
TABLE I 1 Continued

\begin{tabular}{|c|c|c|c|c|c|c|c|c|}
\hline \multicolumn{9}{|c|}{ Southern and northern banks } \\
\hline \multirow{3}{*}{$\begin{array}{c}\text { Sample No. } \\
\text { Wt. } \%\end{array}$} & \multicolumn{8}{|c|}{ Gypsum microbialite (stromatolite) } \\
\hline & $1 \mathrm{~A}$ & $1 \mathrm{Q}$ & $2 Q$ & $3 Q$ & 4Q & $5 Q$ & $8 \mathrm{~A}$ & 9A \\
\hline & & & & & & & & \\
\hline $\begin{array}{l}\text { Combined } \\
\mathrm{H}_{2} \mathrm{O}\left(250 \mathrm{C}^{\circ}\right)\end{array}$ & 19.08 & 17.67 & 16.58 & 17.68 & 17.64 & 18.11 & 17.59 & 16.82 \\
\hline $\mathrm{SO}_{3}$ & 43.48 & 40.82 & 39.54 & 41.35 & 41.86 & 41.11 & 40.83 & 39.74 \\
\hline $\mathrm{CaO}$ & 30.10 & 29.52 & 29.62 & 29.45 & 30.29 & 29.44 & 29.83 & 27.99 \\
\hline $\mathrm{Al}_{2} \mathrm{O}_{3}$ & 0.17 & 0.22 & 0.50 & 0.29 & 0.17 & 0.20 & 0.83 & 0.87 \\
\hline $\mathrm{Fe}_{2} \mathrm{O}_{3}$ & 0.12 & 0.16 & 0.37 & 0.20 & 0.10 & 0.15 & 0.62 & 0.64 \\
\hline $\mathrm{MgO}$ & 0.37 & 0.49 & 0.44 & 0.45 & 0.42 & 0.41 & 0.45 & 0.64 \\
\hline $\mathrm{SiO}_{2}$ & 0.86 & 1.50 & 3.80 & 2.54 & 1.26 & 1.94 & 3.35 & 0.44 \\
\hline $\mathrm{TiO}_{2}$ & ------ & ----- & 0.06 & ------ & ------ & ------ & 0.10 & 0.10 \\
\hline $\mathrm{P}_{2} \mathrm{O}_{5}$ & 0.02 & 0.02 & 0.02 & ------ & 0.01 & 0.01 & 0.02 & 0.02 \\
\hline $\mathrm{Na}$ & 0.78 & 1.23 & 1.07 & 1.11 & 1.38 & 1.36 & 0.79 & 1.60 \\
\hline $\mathrm{K}$ & 0.05 & 0.06 & 0.10 & 0.07 & 0.07 & ------ & 0.10 & 0.12 \\
\hline $\mathrm{Cl}$ & 1.24 & 2.00 & 1.88 & ------ & 2.35 & 2.50 & 1.34 & ------ \\
\hline \multicolumn{9}{|l|}{ ppm } \\
\hline $\mathrm{Sr}$ & 4561 & 3534 & 3557 & ------ & 2940 & 3385 & 3283 & ------ \\
\hline $\mathrm{Ba}$ & 166 & 166 & 104 & ------ & 138 & 143 & 127 & ------ \\
\hline $\mathrm{Ni}$ & 41 & 40 & 8 & ------ & 41 & 55 & 42 & ------ \\
\hline $\mathrm{Rb}$ & 13 & 3 & 9 & ------ & 13 & 12 & 7 & ------ \\
\hline $\mathrm{Zn}$ & 13 & 8 & 8 & ------ & 14 & 11 & 15 & ------ \\
\hline $\mathrm{Mn}$ & 192 & 100 & 84 & ------ & ------ & 18 & 212 & ------ \\
\hline $\mathrm{Cu}$ & 36 & 41 & 38 & ------ & 9 & 43 & ----- & ------ \\
\hline $\mathrm{Br}$ & 49 & 46 & 155 & ------ & 55 & 60 & 150 & ------ \\
\hline \multicolumn{9}{|l|}{ Wt. $\%$} \\
\hline $\begin{array}{l}\text { Combined } \\
\mathrm{H}_{2} \mathrm{O}\left(550 \mathrm{C}^{\circ}\right)\end{array}$ & 2.32 & 3.35 & 3.34 & 3.79 & 2.99 & 2.24 & 2.70 & 2.89 \\
\hline $\begin{array}{l}\text { Moisture } \\
\left(\mathrm{H}_{2} \mathrm{O}-45 \mathrm{C}^{\circ}\right)\end{array}$ & 0.19 & 0.15 & 0.17 & 0.15 & .22 & 0.07 & 0.14 & 0.18 \\
\hline L.O.I & 22.8 & 23.70 & 22.30 & 22.40 & 22.90 & 22.80 & 21.60 & 21.90 \\
\hline $\begin{array}{l}\text { Estimated } \\
\mathrm{CO}_{2}\end{array}$ & 1.21 & 2.53 & 2.21 & 0.78 & 2.05 & 2.38 & 1.17 & 2.01 \\
\hline
\end{tabular}

Normative

Wt. \%

$\begin{array}{cllllllll}\text { Gypsum } & 91 & 84 & 79 & 85 & 84 & 87 & 84 & 80 \\ \text { Anhydrite } & 1 & 3 & 5 & 3.5 & 4.5 & 1.5 & 3 & 4\end{array}$

$\begin{array}{llllllllll}\text { Calcite } & -- & 0.5 & 2 & -- & 0.7 & 0.5 & 1 & --\end{array}$

$\begin{array}{cllllllll}\text { Dolomite } & -- & 2 & 2 & -- & 2 & 1 & 2 & -- \\ \text { Halite } & 0.74 & 2.39 & 2.39 & 2.24 & 1.10 & 2.8 & 1.1 & 3.12 \\ \text { Aggregates } & 1.15 & 2.15 & 4.67 & 3.03 & 1.53 & 2.29 & 4.8 & 3.95\end{array}$




\begin{tabular}{|c|c|c|c|c|}
\hline \multirow{3}{*}{$\begin{array}{c}\text { Sample No. } \\
\text { Wt. \% }\end{array}$} & \multicolumn{4}{|c|}{ Bottom sediments } \\
\hline & \multirow{2}{*}{$\begin{array}{c}\begin{array}{c}N e w \\
\text { precipitates }\end{array} \\
11 \mathrm{Q} \\
\end{array}$} & \multicolumn{3}{|c|}{ Gypsum microbialite } \\
\hline & & 1B & $2 \mathrm{~B}$ & $3 B$ \\
\hline $\begin{array}{l}\text { Combined } \\
\mathrm{H}_{2} \mathrm{O}\left(250 \mathrm{C}^{\circ}\right)\end{array}$ & 16.85 & 8.12 & 14.07 & 15.93 \\
\hline $\mathrm{SO}_{3}$ & 42.80 & 24.25 & 39.98 & 40.13 \\
\hline $\mathrm{CaO}$ & 29.88 & 21.79 & 27.61 & 27.58 \\
\hline $\mathrm{Al}_{2} \mathrm{O}_{3}$ & 0.75 & 3.98 & 0.92 & 0.79 \\
\hline $\mathrm{Fe}_{2} \mathrm{O}_{3}$ & 0.54 & 2.30 & 0.62 & 0.46 \\
\hline $\mathrm{MgO}$ & 0.39 & 1.67 & 0.53 & 0.72 \\
\hline $\mathrm{SiO}_{2}$ & 2.75 & 19.80 & 4.17 & 4.35 \\
\hline $\mathrm{TiO}_{2}$ & ----- & ------ & ----- & ------ \\
\hline $\mathrm{P}_{2} \mathrm{O}_{5}$ & 0.03 & 0.10 & 0.04 & 0.03 \\
\hline $\mathrm{Na}$ & 0.71 & 1.97 & 1.27 & 1.38 \\
\hline $\mathrm{K}$ & 0.08 & 0.45 & 0.12 & 0.12 \\
\hline $\mathrm{Cl}$ & 0.9 & 2.54 & 2.16 & 2.09 \\
\hline \multicolumn{5}{|l|}{$\mathrm{ppm}$} \\
\hline & ------ & 3071 & 2716 & 3611 \\
\hline $\mathrm{Ba}$ & ------ & 240 & 116 & 154 \\
\hline $\mathrm{Ni}$ & ------ & ------ & 31 & 36 \\
\hline $\mathrm{Rb}$ & ------ & ----- & 12 & 4 \\
\hline $\mathrm{Zn}$ & ------ & 47 & 30 & 11 \\
\hline $\mathrm{Mn}$ & ------ & 393 & 218 & 63 \\
\hline $\mathrm{Cu}$ & ------ & ----- & 22 & 70 \\
\hline $\mathrm{Br}$ & ------ & 255 & 62 & 62 \\
\hline Wt.\% & & & & \\
\hline $\begin{array}{l}\text { Combined } \\
\mathrm{H}_{2} \mathrm{O}\left(550 \mathrm{C}^{\circ}\right)\end{array}$ & 2.89 & 7.67 & 5.55 & 3.37 \\
\hline $\begin{array}{l}\text { Moisture } \\
\left(\mathrm{H}_{2} \mathrm{O}-45 \mathrm{C}^{\circ}\right)\end{array}$ & 0.26 & 1.09 & 0.26 & 0.79 \\
\hline L.O.I & 21.49 & 22.59 & 23.99 & 23.59 \\
\hline $\begin{array}{l}\text { Estimated } \\
\mathrm{CO}_{2}\end{array}$ & 4.38 & ------ & 4.11 & 3.50 \\
\hline \multicolumn{5}{|l|}{$\begin{array}{c}\text { Normative } \\
\text { Wt. } \%\end{array}$} \\
\hline Gypsum & 81 & 39 & 67 & 76 \\
\hline Anhydrite & 9 & 10.5 & 15 & 8 \\
\hline Calcite & -- & 4 & -- & -- \\
\hline $\begin{array}{l}\text { Aggregates } \\
\text { (Clay } \\
\text { fraction) }\end{array}$ & 4.04 & 26.08 & 5.71 & 5.60 \\
\hline
\end{tabular}

